\title{
Album Jana Ludevíta Procházky z let 1860 - 1888 / The Procházka Album (1860-1888)
}

K vydání připravila Jana VOJTĚŠKOVÁ. Praha : KLP - Koniasch Latin Press a Národní muzeum, 2013. LXVI + 350 stran. ISBN 978-80-87773-00-0 (KLP), ISBN 978-807036-383-6 (NM)

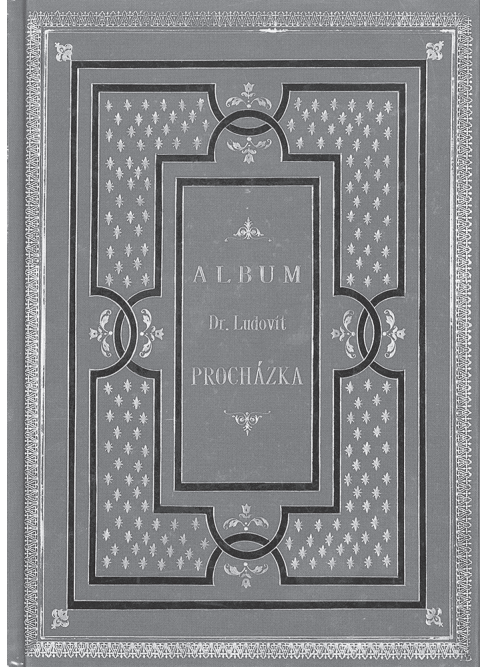

Roku 2013 vydalo pražské nakladatel'stvo Koniasch Latin Press v spolupráci s českým Národním muzeom pramenno-kritickú edíciu Albumu Jana Ludevíta Procházku z rokov 1860 až 1888 . Album, ktorý je súčastou zbierkových fondov Národního muzea - Českého muzea hudby v Prahe, predstavuje unikátny súbor Procházkovi adresovanej a väčšinou doposial' nevydanej korešpondencie a pamätných zápisov, vrátane niekolkých listov, ktoré majú iného adresáta. Význam tejto vzácnej pamiatky $\mathrm{z}$ druhej polovice 19 . storočia podčiarkuje jej kvalitné pramenno-kritické spracovanie, reprezentatívna výtvarná adjustáž na kriedovom papieri, atraktívna pevná väzba knihy s aplikáciou súdobých výtvarných knižných motívov, a napokon aj bilingválny český a anglický text, vd’aka čomu je publikácia prístupná nielen českému (a slovenskému), ale aj zahraničnému záujemcovi o danú problematiku. Edícia ako súčast’ riešenia grantového projektu Národního muzea bola podporená
Ministerstvom kultúry ČR v rámci inštitucionálneho financovania koncepčného rozvoja výskumnej organizácie Národní muzeum a aj vydaná s podporou spomínaného ministerstva.

Meno významnej osobnosti pražského hudobného života 60. a 70. rokov 19. storočia Ludevíta Procházku je známe aj v slovenskej hudobnohistorickej spisbe. Ako podporovatel' a priaznivec hudobného skladatela Jána Levoslava Bellu sa zasadil o to, aby Bellove diela zazneli v 70. rokoch 19. storočia v Prahe, medzi nimi pôvodná premiéra symfonickej básne Osud a ideál (1876). Vdaka Procházkovi sa Bella na svojej študijnej ceste (1873), ktorá zahrnovala aj pobyt v Prahe, osobne zoznámil s významnými súvekými českými skladatelmi, a napokon bol to - prísne vzaté - práve on, kto stál v pozadí Bellovho hudobnoštýlového prerodu. Pramenno-kritické vydanie Procházkovho albumu sa preto sčasti dotýka aj slovenských hudobných dejín.

Editorka Jana Vojtešková, vedecká pracovníčka Národního muzea - Českého muzea hudby v Prahe, pozná špecifiká editovania korešpondencie hudobníkov velmi dobre, kedže pred časom vydala edične výborne spracovanú korešpondenciu známeho českého skladatela Josefa Suka. Svoje skúsenosti tak zúročila aj v recenzovanom Procházkovom albume a pripravila edíciu po obsahovej, koncepčnej, metodologickej, ako aj pramenno-kritickej stránke na vysokej úrovni. Publikácia sa člení na dve časti: v prvej časti sa $\mathrm{v}$ zmysle hudobnohistorického úvodu/uvedenia do problematiky charakterizuje editovaná pamiatka z rôznych aspektov, druhá čast' je vlastnou edíciou albumu rozšírenou o muzikologické komentáre k editovaným listovým jednotkám a pamätným zápisom. 
Prvá čast’ zahrnuje genézu prameňa, koncízne spracované biografické profily manželov Ludevíta a Marty Procházkovcov, vyhodnotenie obsahu a kontextov editovanej korešpondencie, edičné zásady a kodikologický popis albumu, ako aj rôzne prehladové tabulky, vrátane kalendária $\mathrm{k}$ životu a dielu oboch manželov (s. ix - xxxiii, uvádzame odkaz len na českú jazykovú mutáciu). Genéza a osudy pamiatky sú viac ako pozoruhodné, preto sa tu o nich v krátkosti zmienim. Dozvedáme sa, že pamiatka bola zostavená pravdepodobne až po Procházkovej smrti z pôvodného albumu, resp. súboru korešpondencie adresovanej manželom Procházkovcom. Album sa postupne dostal do vlastníctva niekol'kých českých súkromných zberatelov, v súkromnom vlastníctve zostal aj po dražbe v berlínskom aukčnom dome J. A. Stargardt (1908). Súčastou zbierok Českého muzea hudby, a tým aj vlastníctvom štátu sa stal až roku 2003. Krátky časový horizont, $\mathrm{v}$ akom bol Procházkov album vedecky spracovaný a pripravený na publikovanie, tiež vypovedá o výnimočnej historickej hodnote pamiatky.

Ludevít Procházka (1837 - 1888) patrí k muzikologicky reflektovaným osobnostiam najmä v českej, sčasti aj zahraničnej literatúre. Pre danú edíciu bolo však prínosné zaradenie jeho koncízneho biografického profilu, pretože umožňuje lepšie porozumiet' personálnym aj tematickým kontextom, ako vyplývajú $\mathrm{z}$ analýzy korešpondencie. Ešte väčšmi treba podčiarknut zaradenie biografického profilu jeho manželky, speváčky Marty Procházkovej, rodenej Reisingerovej (1849 - 1903), lebo $\mathrm{k}$ jej životu je bežne známych iba málo poznatkov. Dr. Ludevít Procházka vyštudoval podobne ako viacerí jeho súčasníci síce právo, ale napokon sa plne venoval hudbe - ako klavirista, skladatel', dirigent, pedagóg, hudobný kritik, editor a organizátor koncertov. Jana Vojtěšková vyzdvihla šírku jeho vzdelania a aktivít, ako aj mimoriadny hudobný rozhlad a nadšenie, $s$ akým presadzoval modernú českú hudbu a ako Smetanov žiak zvlášt dielo svojho učitela. Propagovaniu českej hudby sa venoval tak počas svojho pôsobenia v Prahe, ako aj v Nemecku (Hamburg, Drážd’any), kde jeho manželka Marta Procházková získala operné angažmán. Jeho aktivity organizátora koncertov sa spájali najmä so spolkovou činnostou, obdivuhodne bohatá bola aj jeho činnost' hudobného publicistu.

$\mathrm{V}$ analýze obsahovej zložky editovanej pamiatky s podtitulom Procházkovy kontakty $v$ zrcadle jeho alba sa Jana Vojtěšková vyjadrila v tom zmysle, že album bol pravdepodobne zostavený s úmyslom poukázat na neobyčajnú šírku Procházkových umeleckých kontaktov (s. x), s čím možno plne súhlasit, pričom ide o osobnosti tak z hudobného, ako aj z mimohudobného prostredia. Obsahová analýza (s. $\mathrm{x}$ - xvii) zohladnila časovú os, čiže chronologický, ale aj tematický aspekt, čo vytvorilo istú žiaducu komplementaritu voči editovanej korešpondencii, zoradenej prevažne abecedne podla pisatelov/adresantov, kde v popredí stojí individuálny aspekt osobností. V analýze sa detailnejšie reflektujú Procházkove aktivity, ako vyplývajú z obsahu publikovanej korešpondencie a pamätných/spomienkových zápisov: jeho spolková, edičná a kompozičná činnost', pražská premiéra Lisztovho oratória Legenda o sv. Alžbete (1866) a v kontexte s tým aj uvedenie Lisztovho zboru Slavimo slavno Slaveni! (1866) v Prahe, záujem o hudbu starších období a historické koncerty, podpora uvádzania diel Leopolda Eugena Měchuru a Měchurove kompozično-estetické postrehy, význam Bellovho kontaktu s Procházkom, kontakty so slovanskými umelcami a vôbec slavistami, ako aj písomné kontakty $s$ početnými hudobnými skladatelmi, interpretmi a hudobnými kritikmi a dalšie témy. Bližšie sa rozoberajú aj tri listy adresované Marte Procházkovej od Hansa Richtera, Carla Goldmarka a Marthy Remmertovej súvisiace $s$ jej interpretačnou činnostou a speváckym umením. Zaujali aj zmienky o hudobnom salóne manželov Procházkovcov.

Užitočnou pomôckou sú vyššie spomínané prehladové tabulky $\mathrm{k}$ rôznym druhom údajov. Umožňujú lahkú orientáciu v edícii, či už z hladiska adresantov, profesijného zamerania, chronológie, jazykovej stránky alebo typu dokumentu (list, pamätný zápis a pod.). V albume sa nachádzajú tri listy adresované manželke Marte a pät iným adresátom, ktoré však tiež preukazujú súvislost' s osobou 
Ludevíta Procházku. V kodikologickom popise pamiatky upútala podoba krstného mena Procházku v názve albumu na väzbe: „Album / Dr. Ludovít [!] / Procházka“ (s. xx).

Výber relevantnej metódy a koncepcie pri vydaní korešpondencie ako pramenno-kritickej edície je spravidla určovaný charakterom pramenného materiálu. $\mathrm{V}$ druhej časti publikácie (s. 1 - 333) uplatnila editorka Jana Vojtěšková pri práci s pramenným materiálom najnovšie filologické metódy. Jej profesionálny prístup sa odzrkadluje v korektnej textovej kritike s citlivým vnímaním dobových reálií a kontextov. Tento zretel' je podporený doplňujúcimi hudobnohistorickými komentármi, v ktorých sa odráža celkový rozhlad editorky v súvekej aj novšej literatúre, ale aj výsledky dalšieho pramenného výskumu. Editovaná korešpondencia je písaná v ôsmich jazykoch, a tak k dôležitým predpokladom a pracovným nástrojom patrila aj znalost' cudzích jazykov. Najviac korešpondenčných jednotiek je písaných v češtine a nemčine, početne menšie skupinky listov a pamätných zápisov vytvárajú pramene písané v anglickom, madarskom, polskom, ruskom, talianskom a slovenskom jazyku. Duktus písma rôznych adresantov sa pohybuje od kaligraficky úhladného po tažšie čitatelné písmo (najmä v nemeckom rukopisnom kurente).

Každá korešpondenčná jednotka je transkribovaná $\mathrm{v}$ originálnom jazyku formou diplomatického prepisu. Navyše súčasný rozmach reprografickej techniky umožnil začlenit do publikácie aj kvalitnú obrazovú reprodukciu kompletného prameňa. Rozsiahle využitie ikonografického prvku malo však oporu aj v samotnom pramennom materiáli. Okrem listov s notovými ukážkami album totiž obsahoval aj pramene pamätného či spomienkového charakteru so zápisom hudby, $\mathrm{v}$ ktorých dominoval notový zápis a text $\mathrm{s}$ venovaním bol skôr len doplnkom. Okrem prepisu a faksimile štruktúra každej editovanej jednotky albumu obsahuje d’alej - bilingválne česky a anglicky - základné dokumentačné údaje a regest editovaného prameňa $s$ bohatým poznámkovým aparátom pod čiarou, ktorý sa týka osôb, udalostí, názorov a d’alších záležitostí vyskytujúcich sa v transkribova- nom texte. Súčastou tejto štruktúry je tiež bio-bibliografický medailón pisatela. Slúži editorke ku cti, že neopomenula žiaden detail a že medailóny osobností sú spracované dôsledne a koncízne, či už šlo o významnú alebo málo známu osobnosté.

S nadhladom a dokumentačne precízne sú vyriešené rôzne problematické otázky súvisiace $s$ editovaním albumu, ktoré sa na prvý pohlad javia ako celkom jednoduché. Ako príklad spomeniem číslovanie editovaných jednotiek. $Z$ edičných zásad vyplýva (s. xix), že edícia zachováva pôvodné radenie jednotiek v albume, avšak prináša nové číslovanie, presnejšie sčasti pôvodné a sčasti nové. Nové číslovanie zohladňuje dve skutočnosti. Prvou je, že album obsahoval aj niekolko pôvodne nečíslovaných jednotiek. Tieto si v edícii zachovávajú svoje poradie $\mathrm{v}$ albume, ale sú v číslovaní odlíšené pridaním písmena a alebo b k poradovému číslu, čím sa síce narušila abecedná postupnost', ktorá je však kompenzovaná v jednej z prehladových tabuliek (Abecední prehled pisateli̊, s. xxi - xxvi). Druhá skutočnost’ sa týka dávnejšie strateného listu významného českého maliara a ilustrátora Josefa Mánesa. V snahe o zachovanie kompletnosti albumu bol opodstatnene do edície zahrnutý informačný údaj o tomto liste $\left[{ }^{*} 85\right]$ a v následnom graficky odlíšenom dvojitom číslovaní editovaných jednotiek sa už rozlišuje medzi novým a pôvodným číslovaním - $85\left[{ }^{\star} 86\right]$ atd. Edícia Procházkovho albumu má tak dnes 169 [*170] číslovaných jednotiek s tým, že reálny počet editovaných jednotiek, vrátane údaja o stratenom Mánesovom liste, vyjadruje číslo 177 . Reprezentačná funkcia albumu však znamená, že ide o výber zo zbierky korešpondencie, ktorá pôvodne musela byt podstatne rozsiahlejšia. $\mathrm{V}$ priebehu prác na edícii sa navyše $\mathrm{v}$ antikvariáte objavili štyri obálky, ktoré pôvodne patrili $\mathrm{k}$ albumu. Tieto boli zakúpené pražskou Nadáciou pre dejiny kultúry v strednej Európe a ich reprodukcie s príslušnými údajmi ako dodatok Appendix (s. 333) boli tiež zahrnuté do edície.

V albume je zastúpených 116 osobností jednou, eventuálne niekolkými editovanými 
jednotkami, $\mathrm{k}$ tomu navyše treba pripočítat jeden vokálny ensemble s kolektívnou pamätnou hudobnou dedikáciou. Z hladiska profesijného zamerania dominujú, prirodzene, hudobníci a hudobní teoretici (skladatelia, interpreti, pedagógovia, organizátori, hudobní historici a publicisti), ale v menšej miere nájdeme aj zástupcov inej umeleckej sféry (literáti, maliari, herečka) a dalších profesií (filológ, kňaz, právnik, advokát, politik). Každý list alebo pamätný zápis, či už ide o významnú alebo menej významnú osobnost', je niečím zaujímavý a vydáva autentické svedectvo o svojej dobe. Spomeniem výberovo ad demonstrandum len niekolko mien pisatelov listov: A. W. Ambros, J. K. Arnold, A. Auspitz-Kolárová, J. L. Bella, E. Šrámková-Bubeníčková, $H$. von Bülow, A. Dvořák, R. Eitner, A. S. Famincyn, A. Förchtgott Tovačovský, C. Goldmark, H. Heřmánek, B. Jablonský, A. Joachim, P. Kř́žkovský, L. Leger, F. Liszt, L. E. Měchura, H. Richter, A. G. Rubinštejn, T. Sladovník, B. Smetana, A. W. Thayer, V. V. Timanova, J. V. Veit. Pozoruhodný fenomén predstavujú v albume už spomínané jednotky typu pamätných hudobných zápisov s venovaním, medzi nimi od pisatelov ako J. L. Bella, V. V. Bezekirskij, A. Dvořák, E. Chiomi, J. Fabián, W. Górski, A. N. Jesipova, H. Kàan von Albest, W. Kienzl, A. S. Famincyn, Z. Fibich, A. Peka, N. Plotényi, L. Procházka (B. Smetanovi), E. Reményi, členovia vokálneho Ruského okteta, B. Smetana, C. Viala, W. Żeleński. V pamätných hudobných zápisoch možno vidiet' nielen dobové špecifikum, ale aj analógiu medzi hudobno-žánrovým typom najmä klavírnych skladieb s názvami Lístok v pamätníku (Albumblatt). Je len logické, že sa v týchto hudobných zápisoch odráža tiež hudobná individualita pisatela.

Už staršia hudobná historiografia si uvedomovala, že velikáni hudby stoja síce na vrchole pomyselnej pyramídy umenia, základy vyspelej hudobnej kultúry tvorí však dobrá hudobno-organizačná štruktúra a aktivity hudobníkov na regionálnej a lokálnej úrovni. Ak šírku umeleckých kontaktov Procházku prezentuje $\mathrm{v}$ albume početnost’ personálneho zastúpenia, podobne šírku jeho hudobnokultúrnych a umeleckých záujmov dokladá obsahová rozmanitost' a pestrost tém, obsiahnutých v korešpondencii. Táto rozmanitost’ môže poslúžit ako cenný zdroj poznatkov pri skúmaní a spracovávaní dalších parciálnych tematických okruhov, ako napríklad koncertná prevádzka, recepcia hudby, kompozičná poetika, hudobnoestetické náhliady, ludová pieseň a jej spracovanie, slovanofilské idey a mnohé d’alšie.

Korešpondencia patrí síce primárne do kategórie historických dokumentov, prináša však rovnako privátne ako všeobecne historické svedectvá. V editovaných textoch vystupuje preto ako nápadný znak individuálny písomný prejav a jazykový štýl pisatelov, ale zároveň celkovo obdivuhodná kultivovanost’ ako obraz medziludských vztahov a súvekého spoločenského prostredia, v ktorom sa Procházka pohyboval. Z obsahového a vecného aspektu edícia sústreduje množstvo cenných poznatkov $\mathrm{k}$ problematike hudobnej kultúry stredoeurópskeho priestoru. Potvrdzuje tiež, že 19. storočie je obdobím rozkvetu korešpondencie ako komunikačného média.

Rada by som v závere ešte raz vyzdvihla vysokú vedeckú úroveň edície albumu Ludevíta Procházku, ktorá sa týka každého jej parametra, vrátane reprografickej zložky a anglickej jazykovej mutácie. Zároveň ponúka pútavé čítanie aj možnosť komparácie transkribovaného textu a faksimile. Vdaka znamenitej vedeckej akríbii editorka Jana Vojtěšková aktualizovala predloženou edíciou na vysokej profesionálnej a muzikologickej úrovni odkaz tejto pozoruhodnej osobnosti. Kvalitne editovaná pamiatka predstavuje dôležitú pamätovú stopu, dotýkajúcu sa tak dejín českého národného spoločenstva, ako širšieho stredoeurópskeho priestoru.

Jana Lengová 